\title{
PENGARUH TINGKAT PEMBERIAN PUPUK BOKASHI TERHADAP PRODUKSI HIJAUAN SORGUM MANIS (Sorghum bicolor [L.] Moench)
}

\author{
Risna $^{1)}$, B. Nohong, ${ }^{2 *}$ Rinduwati ${ }^{2)}$ \\ ${ }^{1)}$ Mahasiswa Program Strata Satu Departemen Nutrisi dan Makanan Ternak, \\ Fakultas Peternakan, Universitas Hasanuddin. \\ ${ }^{2)}$ Dosen Departemen Nutrisi dan Makanan Ternak, Fakultas Peternakan, \\ Universitas Hasanuddin. \\ *E-mail: budiman_ek58@yahoo.com
}

\begin{abstract}
This research was conducted to determine the effect of bokashi fertilizer level on the production of sweet sorghum forage.The study was arranged in a completely randomized design consisting of four treatments and four replications. The treatments given are as follows: T0: Control; T1: Bokashi fertilizer $60 \mathrm{t} / \mathrm{ha}$, equivalent to $300 \mathrm{~g} /$ polybag; T2: Bokashi Fertilizer $100 \mathrm{t} / \mathrm{ha}$, equivalent to 500 $\mathrm{g} /$ polybag; T3: Bokashi fertilizer of $140 \mathrm{t} / \mathrm{ha}$, equivalent to $700 \mathrm{~g} / \mathrm{polybag}$. The results showed that bokashi fertilizer significantly affected $(\mathrm{P}<0.05)$ the production of fresh forages and dry matter in sweet sorghum plants. Duncan test showed that the production of fresh forage and dry matter on $\mathrm{T} 1$ treatment $(\mathrm{P}<0.05)$ higher than the production of fresh and dry matter forage on the T0 (control). Production of fresh forage and dry matter on $\mathrm{T} 2$ and $\mathrm{T} 3$ treatments were significantly $(\mathrm{P}<0.01)$ higher than the production of fresh and dry matter forage on the T0 (control). While the production of fresh forage and dry matter on $\mathrm{T} 2$ and $\mathrm{T} 3$ treatment was not significantly different $(\mathrm{P}>0.05)$. It was concluded that the dose of Bokashi fertilizer to the level of $100 \mathrm{t} / \mathrm{ha}(500 \mathrm{~g} / \mathrm{polybag})$ increase the production of fresh and dry matter of sweet sorghum.
\end{abstract}

Keyword : Dry matter production, fresh forage production, bokashi fertilizer, sweet sorghum.

\begin{abstract}
ABSTRAK
Penelitian ini dilakukan untuk mengetahui pengaruh level pemberian pupuk bokashi terhadap produksi hijauan sorgum manis. Penelitian disusun dalam rancangan acak lengkap yang terdiri atas empat perlakuan dan empat kali ulangan.Perlakuan yang diberikan sebagai berikut : $\mathrm{T}_{0}$ : Kontrol (tanpa pupuk); $\mathrm{T}_{1}$ : Pupuk Bokashi 60 ton/ ha setara dengan $300 \mathrm{~g} /$ polybag; $\mathrm{T}_{2}$ : Pupuk Bokashi $100 \mathrm{ton} / \mathrm{ha}$ setara dengan 500 g/polybag; $\mathrm{T}_{3}$ : Pupuk Bokashi 140ton/ha setara dengan $700 \mathrm{~g} /$ polybag. Hasil penelitian menunjukkan bahwa pemberian pupuk bokashi berpengaruh nyata $(\mathrm{P}<0,05)$ terhadap produksi hijauan segar dan bahan kering pada tanaman sorgum manis. Uji Duncan menunjukkan bahwa produksi hijauan segar dan bahan kering pada perlakuan $\mathrm{T}_{1}$ nyata $(\mathrm{P}<0,05)$ lebih tinggi dibanding dengan produksi hijauan segar dan bahan kering pada perlakuan $\mathrm{T}_{0}$ (kontrol). Produksi hijauan segar dan bahan kering pada perlakuan $\mathrm{T}_{2}$ dan $\mathrm{T}_{3}$ sangat nyata $(\mathrm{P}<0,01)$ lebih tinggi dibanding
\end{abstract}


dengan produksi hijauan segar dan bahan kering pada perlakuan $\mathrm{T}_{0}$ (kontrol). Sedangkan produksi hijauan segar dan bahan kering pada perlakuan $\mathrm{T}_{2}$ dan $\mathrm{T}_{3}$ tidak berbeda nyata $(\mathrm{P}>0,05)$. Disimpulkan bahwa pemberian dosis pupuk bokashi sampai level 100 ton/ha (500 g/polybag ) meningkatkan produksi bahan segar dan bahan kering sorgum manis.

Kata kunci: Produksi bahan kering, produksi hijauan segar, pupuk bokashi, sorgum manis

\section{PENDAHULUAN}

Sorgum (Sorghum bicolor [L.] Moench) termasuk tanaman musim yang hangat (jalur fotosintesis $\mathrm{C} 4$ ), tumbuh paling baik di bawah suhu yang relatif tinggi dan dalam kondisi cerah. Seleksi di masa-masa awal itu adalah untuk biji-bijian lebih dari untuk hijauan. Namun, seleksi untuk varietas hijauan telah terjadi selama seratus tahun terakhir. Sorgum hijauan mirip dengan jenis biji tetapi lebih tinggi dan memiliki kualitas hijauan yang lebih tinggi (Vendramini et al. 2016). Tanaman sorgum setidaknya memiliki kerabat 30 spesies, diantara spesies tersebut, yang paling banyak dibudidayakan adalah spesies Sorghum bicolor (Moench) (USDA, 2019).

Sorgum manis, dengan berbagai fitur adaptif dan persyaratan input yang rendah, adalah salah satu kandidat utama untuk bahan baku biofuel. Memiliki potensi untuk menyelesaikan dua masalah utama. Pertama, dapat berperan penting dalam mengatasi meningkatnya kebutuhan akan energi terbarukan untuk menggantikan sumber energi berbasis bahan bakar fosil. Kedua, dapat membantu konservasi lahan marginal dengan mengubahnya menjadi lahan pertanian (Mathur et al,.2017). Sorgum manis memiliki kemampuan untuk mempertahankan kehijauan batang dan daun (stay green) bahkan hingga tanaman mencapai tahap pengisian dan pemasakan biji. Kemampuan stay green penting dalam meningkatkan hasil dan toleransi tanaman terhadap cekaman kekeringan yang terjadi setelah tanaman berbunga (Zubair, 2016). Kemampuan stay green ini juga membuat hijauan sorgum manis tetap dapat dijadikan pakan hijauan segar untuk ternak setelah dilakukan pemanenan biji.

Setiap bahan pakan pada umumnya memiliki zat anti nutrisi, begitupun tanaman sorgum manis. Menurut penelitian Pratiwi (2011), limbah hijauan sorgum manis berpotensi sebagai bahan pakan alternatif dalam upaya menjaga ketersediaan pakan. Tunas sorgum muda atau tanaman sorgum manis yang mengalami stress 
(kekeringan, defisiensi unsur hara, seranga HPT) mengandung kadar HCN (asam sianida) yang tinggi dan dapat berbahaya jika digunakan sebagai pakan ternak. Agar dapat dimanfaatkan sebagai pakan maka daun sorgum manis harus dilayukan lebih dulu selama 2-3 jam untuk menghilangkan kandungan racun tersebut. Daun sorgum manis yang telah dilayukan memiliki nutrisi setara dengan rumput gajah dan pucuk tebu. Setiap bobot kering daun sorgum terkandung 7,82 persen protein kasar, 2,60 persen lemak, 28,94 persen serat kasar, 11,43 persen abu dan 40,57 persen bahan ekstrak tanpa nitrogen (BETN) (Irawan dan Sutrisna, 2011). Collett (2004) menyarankan agar hijauan sorgum manis dipanen setelah memiliki tinggi antara 50 $\mathrm{cm}-100 \mathrm{~cm}$, karena semakin tua umur panen hijauan sorgum manis maka kadar serat kasarnya juga semakin bertambah.

Meskipun sorgum dapat tumbuh pada lahan yang kurang subur, tetapi untuk mendapatkan hasil yang maksimal, maka perlu tambahan unsur hara dari luar dalam bentuk pupuk. Menurut Sisworo ( 2006), bahwa kebanyakan tanah di daerah tropis sangat miskin hara, sehingga siklus unsur hara dalam tanah tidak akan berlangsung tanpa input dari luar. Kekurangan unsur nitrogen ini dapat disuplai melalui pupuk anorganik/sintetis. Karena pupuk anorganik/sintetis adalah komoditas yang mahal dan penggunaan pupuk anorganik yang berlebihan akan memperburuk kondisi fisik tanah, sehingga banyak petani menggunakan pupuk anorganik. Menurut Wantania dkk. (2018) pupuk bokashi merupakan salah satu jenis pupuk organik yang menggantikan kehadiran pupuk kimia (anorganik) dalam menambah kesuburan tanah serta memperbaiki kerusakan fisik, kimia, dan biologi tanah akibat pemakaian pupuk secara berlebihan.

Sehubungan dengan hal tersebut di atas maka penelitian ini bertujuan untuk mengetahui pengaruh level pemberian pupuk bokashi terhadap produksi hijauan sorgum manis.

\section{METODE PENELITIAN}

\section{Waktu dan Lokasi Penelitian}

Penelitian ini dilaksanakan di Fakultas Peternakan Universitas Hasanuddin Makassar, Sulawesi Selatan. Penelitian yang dilaksakan pada bulan Januari 2020 Maret 2020. 


\section{Materi Penelitian}

Alat yang digunakan dalam penelitian ini adalah timbangan analitik, kamera, meterandan alat tulis menulis.

Bahan yang digunakan dalam penelitian ini adalah pupuk bokashi, tanah, benih sorgum manis dan polybag.

\section{Metode Penelitian}

Penelitian menggunakan rancangan acak lengkap (RAL) (Steel dan Torrie, 1993) terdiri dari 4 perlakuan dan 4 ulangan sehingga diperoleh 16 percobaan. Perlakuan yang diberikan sebagai berikut :

$\mathrm{T}_{0}$ : Tanpa Pupuk (kontrol)

$\mathrm{T}_{1}$ : Pupuk Bokashi 60 ton/ ha setara dengan $300 \mathrm{~g} /$ polybag

$\mathrm{T}_{2}$ : Pupuk Bokashi 100 ton/ ha setara dengan $500 \mathrm{~g} / \mathrm{polybag}$

$\mathrm{T}_{3}$ : Pupuk Bokashi 140/ha setara dengan $700 \mathrm{~g} /$ polybag

\section{Persiapan Media Tanam}

Pelaksanaan penelitian dimulai dengan menyiapkan tanah yang akan digunakan. Jenis tanah yang digunakan yaitu tanah ultisol, tanah ini kemudian dihancurkan dan dibersihkan dengan cara diayak. Tanah ditimbang seberat $10 \mathrm{~kg}$ setiap polybag, kemudian dicampur dengan pupuk bokashi sesuai perlakuan level pupuk yang akan diuji. Tanah yang sudah dicampur dengan pupuk bokashi dimasukkan ke dalam polybag berukuran 30 x $40 \mathrm{~cm}$, , kemudian diberi air sampai mencapai kapasitas lapang (persentase kelembaban yang ditahan oleh tanah sesudah terjadinya drainase dan kecepatan gerakan air ke bawah lambat).

\section{Penanaman}

Bibit (biji) yang akan ditanama direndam selama satu malam. Penanaman bibit dilakukan secara langsung dengan menggunakan benih (biji) dengan sistem tuggal, dengan 8-10 benih sorgum per polybag. Setelah tumbuh, kemudian dilakukan penjarangan. Dipilih sebanyak 3 (tiga) tanaman yang tumbuh baik dan seragam untuk dipelihara sebagai bahan penelitian, sedangkan yang lainnya dicabut dan dikeluarkan dari polybag. Tanaman yang tersisa dalam polybag dipelihara diberi air jika secukupnya sampai mencapai umur 60 hari, kemudian dipanen untuk mendapatkan produksinya.

\section{Parameter yang Diamati}

Parameter yang diamati pada penelitian ini adalah produksi hijauan segar dan produksi bahan kering hijauan sorgum manis. 


\section{Pengambilan Data}

Pengambilan data produksi hijauan segar dilakukan dengan memotong tanaman setinggi $5 \mathrm{~cm}$ di atas ermukaan tanah, kemudian ditimbang untuk mendapatkan produksi bahan segarnya.

Produksi bahan kering dilakukan dengan menimbang sampel sebanyak 50 gram setiap unit perlakuan kemudian dikeringkan sampai mencapai berat kosntan untuk mendapatkan bahan keringnya. Persentase bahan kering dihitung menggunakan rumus :

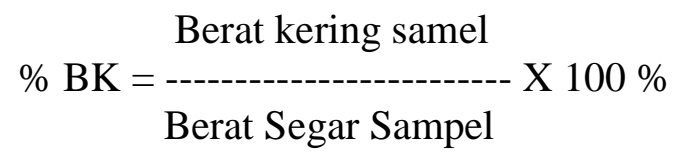

Produksi bahan kering $=\% \mathrm{BK} \times$ Produksi Bahan Segar

\section{Analisis Data}

Data yang terkumpul dianalisis dengan perangkat lunak statistik SPSS dan diuji lanut dengan Duncans Multiple Range Test (DMRT) pada tingkat probabilitas $5 \%$.

\section{HASIL DAN PEMBAHASAN}

\section{Berat Segar Hijauan}

Berdasarkan hasil penelitian yang telah dilakukan diperoleh rata-rata produksi hijauan segar tanaman sorgum manis yang diberi pupuk bokashi berbeda disajikan pada Tabel 1.

Tabel 1.Rata-rata Produksi Hijauan Sorgum (g/polybag) yang Diberi Pupuk Bokashi Berbeda

\begin{tabular}{lcccc}
\hline Parameter & \multicolumn{4}{c}{ Dosis Pupuk Bokashi } \\
\cline { 2 - 5 } & $\mathrm{T}_{0}$ & $\mathrm{~T}_{1}$ & $\mathrm{~T}_{2}$ & $\mathrm{~T}_{3}$
\end{tabular}

\begin{tabular}{lcccc}
\hline Berat segar & $11,00 \pm 2,71^{\mathrm{a}}$ & $216,50 \pm 14,62^{\mathrm{b}}$ & $293,00 \pm 29,90^{\mathrm{c}}$ & $278,75 \pm 23,54^{\mathrm{c}}$ \\
Berat kering & $1,18 \pm 2,71^{\mathrm{a}}$ & $35,73 \pm 14,62^{\mathrm{b}}$ & $46,25 \pm 29,90^{\mathrm{c}}$ & $50,44 \pm 23,54^{\mathrm{c}}$ \\
\hline${ }^{\text {abc. }}$ : Superskrip $\begin{array}{c}\text { yang sama pada baris yang menunjukkan perbedaan yang sangat nyata } \\
(\mathrm{P}<0,01)\end{array}$
\end{tabular}

Hasil analisis ragam pada (Tabel 1) menunjukkan bahwa pemberian pupuk bokashi berpengaruh nyata $(\mathrm{P}<0,05)$ terhadap produksi hijauan segar tanaman 
sorgum manis. Uji Duncan menunjukkan bahwa produksi hijauan segar perlakuan $\mathrm{T}_{1}$ nyata $(\mathrm{P}<0,05)$ lebih tinggi dibanding dengan perlakuan $\mathrm{T}_{0} \quad($ kontrol). Produksi hijauan segar perlakuan $\mathrm{T}_{2}$ dan $\mathrm{T}_{3}$ sangat nyata $(\mathrm{P}<0,01)$ lebih tinggi dibanding dengan produksi hijauan segar perlakuan $\mathrm{T}_{0}$ (kontrol). Sedangkan produksi hijauan segar perlakuan $\mathrm{T}_{2}$ dan $\mathrm{T}_{3}$ tidak berbeda nyata $(\mathrm{P}>0,05)$. Hal ini menunjukkan bahwa makin meningkat pemberian level pupuk bokashi, makin meningkat produksi hijauan segar sorgum manis. Tingginya produksi berat segar pada perlakuan yang diberi pupuk bokashi disebabkan karena meningkatnya ketersediaan unsur hara N, P dan $\mathrm{K}$ dalam tanah yang berasal dari pupuk bokashi yang selanjutnya digunakan untuk pertumbuhan tanaman tersebut hingga pada saat pemotongan. Hal ini sesuai pendapat Lasmadi dkk. (2013) bahwa unsur hara nitrogen yang terdapat pada tanah berfungsi untuk pembentukan atau pertumbuhan bagian vegetatif tanaman, seperti daun, batang dan akar, selain itu unsur $\mathrm{N}$ berfungsi untuk merangsang pertumbuhantanaman secara keseluruhan. Menurut Rahmah (2014) adanya peningkatan biomassa dikarenakan tanaman menyerap air dan hara lebih banyak, unsur hara memacu perkembangan organ pada tanaman seperti akar, sehingga tanaman dapat menyerap hara dan air lebih banyak selanjutnya aktifitas fotosintesis akan meningkat dan mempengaruhi peningkatan berat basah dan berat kering tanaman.

\section{Berat Kering Hijauan}

Rata-rata produksi bahan kering hijauan tanaman sorgum manis yang diberi pupuk bokashi berbeda disajikan pada Tabel 1 .

Hasil analisis ragam pada (Tabel 1) menunjukkan bahwa pemberian pupuk bokashi berpengaruh nyata $(\mathrm{P}<0,05)$ terhadap produksi bahan kering hijauan tanaman sorgum manis. Uji Duncan menunjukkan bahwa produksi bahan kering hijauan perlakuan $\mathrm{T}_{1}$ nyata $(\mathrm{P}<0,05)$ lebih tinggi dibanding dengan produksi bahan kering hijauan perlakuan $\mathrm{T}_{0}$ (kontrol). Produksi bahan kering hijauan perlakuan $\mathrm{T}_{2}$ dan $\mathrm{T}_{3}$ sangat nyata $(\mathrm{P}<0,01)$ lebih tinggi dibanding dengan produksi bahan kering hijauan perlakuan $\mathrm{T}_{0}$ (kontrol). Sedangkan produksi bahan kering hijauan perlakuan $\mathrm{T}_{2}$ dan $\mathrm{T}_{3}$ tidak berbeda nyata $(\mathrm{P}>0,05)$. Tingginya produksi bahan kering hijauan yang diberi pupuk bokashi karena pupuk bokashi mengandung unsur hara makro N, P dan K. Unsur nitrogen dan fosfor digunakan untuk mengatur pertumbuhan tanaman secara keseluruhan. Menurut Lingga (2007) bahwa unsur hara makro nitrogen dalam jumlah yang cukup berperan dalam mempercepat pertumbuhan tanaman secara 
keseluruhan, khususnya batang dan daun, sedangkan kalium berperan sebagai aktivator dari berbagai enzim yang esensial dalam reaksi-reaksi fotosintesis dan respirasi serta enzim yang berperan dalam sintesis pati dan protein (Lakitan, 2000). Melalui penumpukan hasil fotosintesis produksi tanaman semakin meningkat.

\section{KESIMPULAN}

Berdasarkan hasil dan pembahasan maka dapat disimpulkan bahwa pemberian dosis pupuk bokashi sampai level 100 ton/ha (500 g/polybag ) meningkatkan produksi bahan segar dan bahan kering sorgum manis.

\section{DAFTAR PUSTAKA}

Collett I.J. 2004. Forage Sorghum and Millet. Agfact P2.5.41, NSW Department of Primary Industries, New South Wales, AUS.

Irawan, B dan Sutrisna, N. 2011. Proses pengembangan sorgum di Jawa Barat mendukung diversifikasi pangan. Forum Penelitian Agro Ekonomi, 29(2): 99113.

Lakitan. 2011. Dasar-Dasar Fisiologi Tumbuhan. PT. Raja Grafindo Persada. Jakarta.

Lasmadi, R. D., Malalantang S. S., Rustandi, Anis S. D. 2013. Pertumbuhan dan perkembangan rumput gajah drawft (Pennisetum purpureum cv Mott) yang diberi pupuk organik hasil fermentasi EM4. Jurnal Zootek: Vol. 32, No. 5 : 158-171.

Lingga, P. 2007. Petunjuk Penggunaan Pupuk. Penebar Swadaya, Jakarta

Mathur, S., A. V. Umakanth, V. A. Tonapi, R. Sharma and M. K. Sharma. 2017. Biotechnol Biofuels (2017) 10:146

Pratiwi, I.I. 2011. Analisis kandungan ADF dan NDF limbah tiga varietas tanaman sorgum (Sorghum bicolor Moench) sebagai sumber pakan ternakruminansia. J. Agricola 2(2011):149-152.

Rahmah, A. 2014. Pengaruh pupuk organik cair berbahan dasar limbah sawi putih (Brassica Chinensis L.) terhadap pertumbuhan tanaman jagung manis (Zea Mays L. Var. Saccharata). Laporan Penelitian. Universitas Diponegoro.

Sisworo, W.H. 2006. Swasembada Pangan dan Pertanian Berkelanjutan Tantangan Abad Dua Satu : Pendekatan Ilmu Tanah Tanaman dan Pemanfaatan Iptek Nuklir. Badan Tenaga Nuklir Nasional

Steel, R.G.D and J.H. Torrie. 1993. Prinsip dan Prosedur statistika suatu Pendekatan Biometrik, Jakarta. Terjemahan PT Gramedia 
USDA. 2019. Plant Database. Natural Resources Conversation Service.United States Departement of Agriculture.

Vendramini, J., Y. Newman, J. Erickson, W. Vermerris and D. Wright. 2016. Forage Sorgum. IFAS Extension. SS-AGR-333. Universiy of Florida

Wantania, D. I., A. Rumambi., W.B. Kaunang. 2018. Pemanfaatan bokashi feses sapi terhadap produktivitas ratun sorgum varietas kawali. Jurnal Zootek. 38(1) : 916.

Zubair, A. 2016. SORGUM: Tanaman Multi Manfaat. UNPAD Press, Bandung 